\title{
A review of organochlorine and metal pollutants in marine mammals from Central and South America
}

\author{
Assumpción Borrell and Alex Aguilar \\ Department of Animal Biology (Vertebrates), Faculty of Biology, University of \\ Barcelona, Barcelona 08071, Spain \\ Contacte-mail: assump@bio.ub.es
}

\begin{abstract}
Published data on pollutants found in marine mammals from Central and South America are limited. Few species have been studied (18) and sample sizes are usually too small to allow for proper assessment of trends or impacts of pollutants on the populations being studied. The only exceptions to this are the franciscana dolphin from Argentina and the spotted dolphin from the eastern tropical Pacific: the former population studied for organochlorines and the latter for heavy metals. Information on organochlorine levels, mainly on PCBs and DDTs, suggests low levels of exposure when compared to other regions of the world. The ratio DDT/PCB is higher than in other areas, which indicates the predominance of agricultural contamination over that of industrial origin. The generally low DDE/tDDT ratio, particularly in southern America, indicates a recent usage of this pesticide in the region. Levels of mercury were moderate overall, although marine mammals from the areas where contamination by this metal is likely to be higher, such as the Amazon river, have not been studied in this regard. In contrast, mean cadmium and zinc concentrations were higher overall than those in the range typical for northern marine mammals, while copper and lead levels were comparatively low, although information on these latter metals is extremely limited. The lack of comprehensive, long-term studies makes a sound evaluation of the impact of pollutants on the marine mammals from the region unfeasible.
\end{abstract}

KEYWORDS: POLLUTION-ORGANOCHLORINES; POLLUTION-METALS; MARINE MAMMALS; SOUTH ATLANTIC; SOUTH PACIFIC

\section{INTRODUCTION}

Hazardous chemicals such as organochlorine compounds and heavy metals have been dumped in large quantities in the environment for decades and have finally been deposited in the sea (Borrell and Reijnders, 1999). Some of these synthetic chemicals, such as most organochlorines, have high bioaccumulation potential and biomagnify along trophic webs. In contrast, others, such as some metals, have low potential for bioaccumulation and their transfer rate through the food web is limited (Aguilar et al., 1999).

Marine mammals are threatened by these toxic contaminants because many of them occupy high trophic levels, are long-lived, and are therefore able to bioaccumulate high concentrations of these persistent contaminants. Although information on the actual impact of pollutants on marine mammals is scarce (Reijnders et al., 1999), it has been demonstrated that certain organochlorines have a potential for causing reproductive failure and depression of the immune system of seals (e.g. Reijnders, 1986; De Swart et al., 1994).

This review collates information on pollutant levels in marine mammals from Central and South America. In an attempt to ensure the quality of the information collated in this review, only papers published in refereed journals have been included. 


\section{REVIEW OF AVAILABLE INFORMATION}

\section{Organochlorine compounds}

Organochlorine compounds are hydrocarbons with chlorine atoms in their molecules. Only two groups of these are highly resistant to biodegradation and have entered the marine food webs in significant quantities: the DDTs (dichlorodiphenyltrichloroethanes) and the PCBs (polychlorinated biphenyls). Other organochlorine compounds such as hexachlorobenzene (HCB), aldrin, dieldrin, toxaphene, heptachlor epoxide, trans-nonachlor, endrin, $\alpha-\mathrm{HCH}$, $\beta-\mathrm{HCH}$ and lindane $(\tau-\mathrm{HCH})$ have also been detected in the tissues of some marine mammals although their concentrations are usually quite low.

Organochlorine compounds are lipophilic and thus reach their highest concentrations in fatty tissue and, particularly, in the hypodermic fat or blubber. For this reason, and because blubber is readily accessible to sampling both in live and dead individuals, the target tissue in studies devoted to this group of pollutants has traditionally been blubber (Aguilar, 1987). Thus, although some references contain data on organochlorine concentrations in other tissues, the present review considers only those relative to blubber.

\section{Coverage of studies}

Organochlorine concentrations have been reported from 12 cetacean species in Central and South America: three mysticetes and nine odontocetes (Table 1). However, this diversity is not distributed homogeneously either temporally or geographically. Indeed, the data for many species originate solely from Central America, particularly from the Caribbean. From the six odontocete and one mysticete species collected in Central America, with the exception of three dolphin species (Fraser's dolphin, striped dolphin and spinner dolphin) surveyed in the Pacific, the rest (humpback whale, sperm whale, short-finned pilot whale, spinner dolphin and tucuxi) were all studied in the Caribbean Sea. However, even in the Antillean region sample sizes are small, consisting of 11 individuals from four different species. Moreover, most surveys reported from Central America were undertaken during the early 1970s and almost no recent information is available from this area (Fig. 1).

In South America, three odontocete and two mysticete species were examined. The odontocetes studied were the franciscana and Burmeister's porpoise sampled in Argentina and Uruguay from the mid-seventies to the early nineties, and a tucuxi from Surinam sampled in 1971. The mysticete sample was composed of fin and Bryde's whales caught off the coast of Chile by whaling operations in 1983 (Fig. 1).

\section{Levels}

Table 1 details published organochlorine residue concentrations in the blubber of marine mammals from Central and South America. Data are expressed on the basis of $\mu \mathrm{g} . \mathrm{g}^{-\mathrm{I}}$ wet weight, a common basis for calculating concentrations. When data were reported on a lipid weight basis, concentrations were converted into wet weight levels through their tissue lipid content.

In most surveys, sample sizes were small and biological data from specimens studied, particularly age and reproductive status, were not stated. When this information was available, mean organochlorine concentrations were recalculated separately for males and females. In nearly all cases in which the sexes could be separated, organochlorine concentrations were higher in males (Table 1). Males have higher organochlorine concentrations than females because females transfer part of their contaminant burden to their offspring during gestation and lactation; this is the main factor producing an age-related increase in organochlorine loads and levels in males and a decrease in females (Aguilar et al., 1999). However, studies on patterns of age- and sex-related variation in PCB and tDDT 
levels are available only from franciscanas caught in gillnets off Argentina, in which the only significant trend observed was an increase in tDDT levels with age in males; other trends were not significant, probably as a consequence of biased representation of age classes in the sample due to selectivity of incidental capture in gillnets (Borrell et al., 1996).

Overall residue levels found in cetaceans from both Central and South American waters are low. Mean PCB concentrations were in all cases lower than $10 \mu \mathrm{g} . \mathrm{g}^{-1}$ wet weight (range $0.4-9.1 \mu \mathrm{g} . \mathrm{g}^{-1}$ ) in all species. These levels fall within the lower bounds of the range commonly detected in marine mammals from other regions, and are much lower than those associated with reproductive impairment or depression of immunocompetence in seals (e.g. De Swart et al., 1994). Congener specific PCB concentrations have only been reported in Burmeister's porpoises from Argentina (Corcuera et al., 1995).

In general, levels of tDDT were also generally low, although remarkably high concentrations were detected in three small odontocete populations: striped dolphins from the eastern tropical Pacific, with tDDT concentrations averaging $102 \mu \mathrm{g} . \mathrm{g}^{-1}$ in males and $28 \mu \mathrm{g} . \mathrm{g}^{-1}$ in females; franciscanas from Uruguay, the mean tDDT concentrations of which reached $30 \mu \mathrm{g} \cdot \mathrm{g}^{-1}$ in males and $20 \mu \mathrm{g} \cdot \mathrm{g}^{-1}$ in females (O'Shea et al., 1980) and tucuxi from

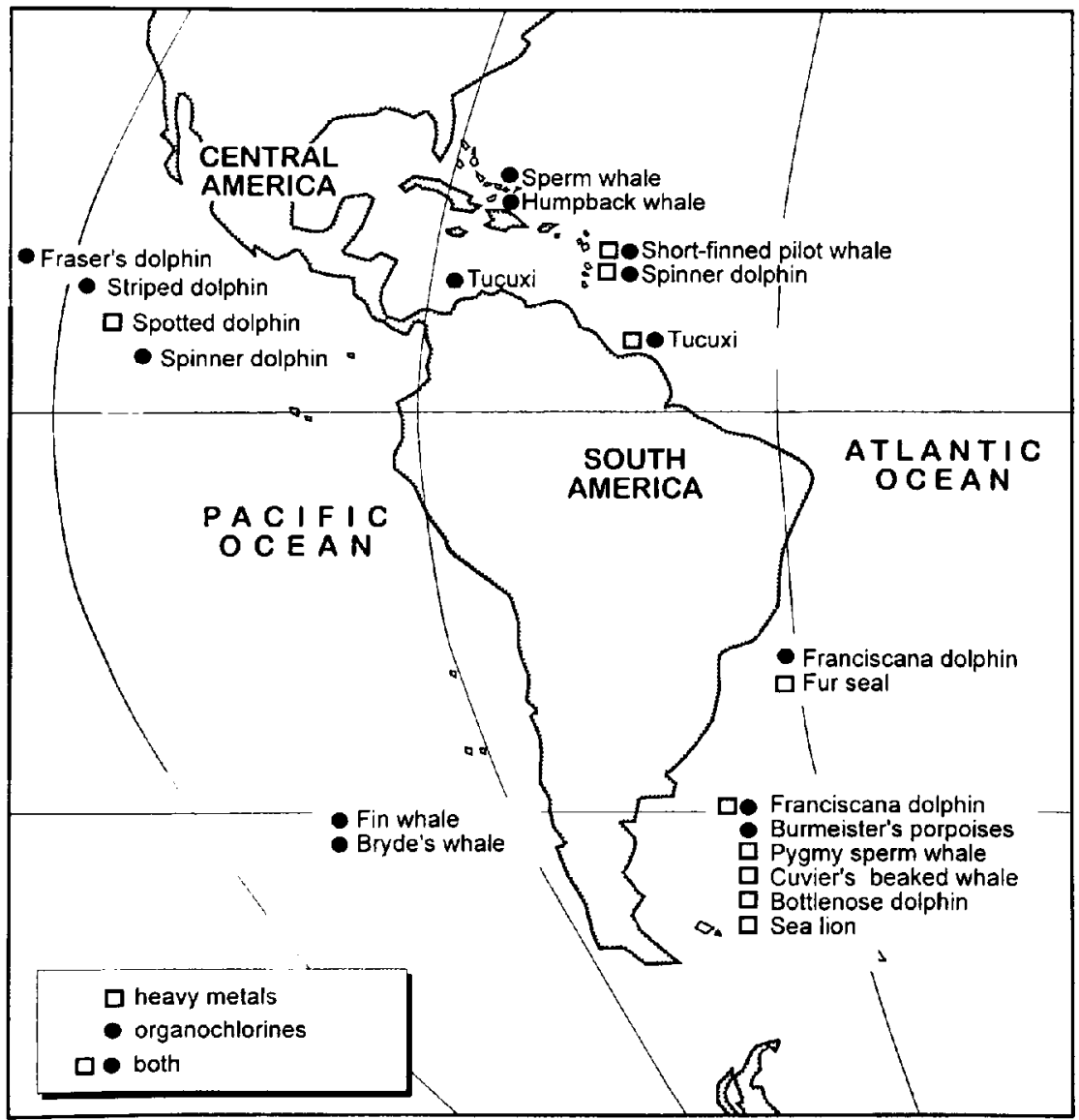

Fig. 1. General location of the marine mammal species analysed from Central and South America. 


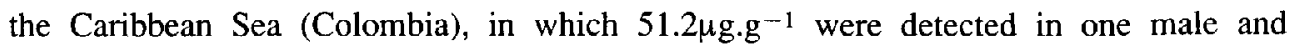
$63.3 \mu \mathrm{g} . \mathrm{g}^{-1}$ in a female (Duinker et al., 1989). The remaining species all had mean levels below $16 \mu \mathrm{g} . \mathrm{g}^{-1}$ (range $0.05-15.5 \mu \mathrm{g} . \mathrm{g}^{-1}$ ) (Table 1).

As one might expect, the two baleen whale species sampled in Chile had significantly lower mean levels of tDDT $\left(0.005-0.6 \mu \mathrm{g} \cdot \mathrm{g}^{-1}\right)$ than the other species (Pantoja et al., 1984). This can be explained by the fact that they feed on krill and are therefore situated low in the trophic web. Surprisingly, however, humpback whales from the Antilles presented comparatively high tDDT levels of $1.75 \mu \mathrm{g} . \mathrm{g}^{-1}$ (Taruski et al., 1975) and, despite being towards the lower bound of the overall concentration ranges, their organochlorine levels were not statistically different from those found in odontocetes in the same region.

Table 1

Organochlorine residue concentrations and relative ratios (mean $\pm \mathrm{SD}$ ) in the blubber of marine mammals from Central and South America.

\begin{tabular}{|c|c|c|c|c|c|c|}
\hline $\begin{array}{l}\text { Species } \\
\text { Code }\end{array}$ & Area/Species & Sex & $\mathbf{n}$ & Date & $\begin{array}{l}\text { Provenance of } \\
\text { researcher }\end{array}$ & Reference \\
\hline & CENTRAL AMERICA & & & & & \\
\hline & ANTILLES & & & & & \\
\hline 1 & $\begin{array}{l}\text { Humpback whale, } \\
\text { Megaptera novaengliae }\end{array}$ & $\mathrm{m}$ & 2 & 1972 & USA & Taruski et al., 1975 \\
\hline 2 & $\begin{array}{l}\text { Sperm whale, } \\
\text { Physeter macrocephalus }\end{array}$ & $\mathrm{m}$ & $\begin{array}{l}1 \\
1\end{array}$ & $\begin{array}{l}1972 \\
1972\end{array}$ & USA & Taruski et al., 1975 \\
\hline 3 & $\begin{array}{l}\text { STA. LUCIA (LESSER ANTILLES) } \\
\text { Short-finned pilot whale, } \\
\text { Glabicephala macrorhynchus }\end{array}$ & $\begin{array}{c}\mathrm{m} \\
\mathrm{f}\end{array}$ & $\begin{array}{l}4 \\
1\end{array}$ & $\begin{array}{l}1972 \\
1972\end{array}$ & Canada & Gaskin et al.. 1974 \\
\hline 4 & $\begin{array}{l}\text { Spinner dolphin, } \\
\text { Stenella longirostris } \\
\text { EASTERN TROPICAL PACIFIC }\end{array}$ & $\begin{array}{c}\mathrm{m} \\
\mathrm{f}\end{array}$ & $\begin{array}{l}1 \\
1\end{array}$ & $\begin{array}{l}1972 \\
1972\end{array}$ & Canada & Gaskin et al., 1974 \\
\hline 5 & $\begin{array}{l}\text { Striped dolphin, } \\
\text { Stenella coeruleoalba }\end{array}$ & $\begin{array}{c}\mathrm{m} \\
\mathrm{f}\end{array}$ & $\begin{array}{c}4 \\
10\end{array}$ & $\begin{array}{l}1973-76 \\
1973-76\end{array}$ & USA & O'Shea et al.,1980 \\
\hline 6 & $\begin{array}{l}\text { Fraser's dolphin, } \\
\text { Lagenodelphis hosei } \\
\text { COLOMBIA }\end{array}$ & $\begin{array}{l}\mathrm{m} \\
-\end{array}$ & 1 & $1973-76$ & USA & O'Shea et al., 1980 \\
\hline 7 & $\begin{array}{l}\text { Tucuxi, } \\
\text { Sotalia fluviatilis }\end{array}$ & $\begin{array}{c}\mathrm{m} \\
\mathrm{f}\end{array}$ & $\begin{array}{l}1 \\
1\end{array}$ & $\begin{array}{l}1977 \\
1977\end{array}$ & Germany & Duinker et al., 1989 \\
\hline & $\begin{array}{l}\text { SOUTH AMERICA } \\
\text { CIILE }\end{array}$ & & & & & \\
\hline 8 & $\begin{array}{l}\text { Fin whale, } \\
\text { Balaenoptera physalus }\end{array}$ & - & 1 & 1983 & Chile & Pantoja et al., 1984, 1985 \\
\hline 9 & $\begin{array}{l}\text { Bryde's whale, } \\
\text { Balaenoptera edeni } \\
\text { URUGUAY }\end{array}$ & - & 2 & 1983 & Chile & Pantoja et al., 1984, 1985 \\
\hline 10 & $\begin{array}{l}\text { Franciscana dolphin, } \\
\text { Pontoporia blainvillei } \\
\text { ARCiENTINA }\end{array}$ & $\begin{array}{l}\mathrm{m} \\
\mathrm{f}\end{array}$ & $\begin{array}{l}5 \\
3\end{array}$ & $\begin{array}{l}1974 \\
1974\end{array}$ & USA & O'Shea et al. 1980 \\
\hline 11 & $\begin{array}{l}\text { Franciscana dolphin, } \\
\text { Pontoporia blainvillei }\end{array}$ & $\mathrm{m}$ & $\begin{array}{l}43 \\
31\end{array}$ & $\begin{array}{l}1988-92 \\
1988-92\end{array}$ & Spain & Borrell et al., 1995 \\
\hline 12 & $\begin{array}{l}\text { Burmeister's porpoises, } \\
\text { Phocoena spinipinnis } \\
\text { SURINAM }\end{array}$ & $\mathrm{m}$ & $\begin{array}{l}4 \\
4\end{array}$ & $\begin{array}{l}1989-90 \\
1989-90\end{array}$ & Spain & Corcuera et al., 1995 \\
\hline 13 & $\begin{array}{l}\text { Tucuxi } \\
\text { Sotalia fluviatilis }\end{array}$ & - & 1 & 1971 & The Netherlands & Koeman et al., 1972 \\
\hline
\end{tabular}


Most studies present results only for PCB and DDT residues. However, O'Shea et al. (1980) also documented levels of other, less ubiquitous, organochlorine compounds in a variety of odontocetes from the region. These compounds, when detected, were always found at extremely low concentrations. In franciscanas, they found mean $\mathrm{HCB}$ concentrations (given to $\pm 1 \mathrm{SD}$ ) were of $0.067 \pm 0.047 \mu \mathrm{g} . \mathrm{g}^{-1}$ in females and $0.08 \pm$ $0.08 \mu \mathrm{g} . \mathrm{g}^{-1}$ in males; the compound was not detected in striped or Fraser's dolphins. Two males out of 13 striped dolphins contained toxaphene and heptachlor epoxide at mean concentrations of $4.8 \pm 0.07$ and $0.28 \pm 0.05 \mu \mathrm{g} . \mathrm{g}^{-1}$ respectively. Endrin occurred at $0.22 \mu \mathrm{g} . \mathrm{g}^{-1}$ in a male striped dolphin, but in no other individuals of that species or in Fraser's dolphin or franciscanas. Trans-nonachlor was detected in six female striped dolphins $(0.19$ $\pm 0.2 \mu \mathrm{g} \cdot \mathrm{g}^{-1}$ ) out of 13 analysed, and in all but one female franciscana (males $0.18 \pm$ $0.04 \mu \mathrm{g} . \mathrm{g}^{-1}$; females $0.073 \pm 0.05 \mu \mathrm{g} . \mathrm{g}^{-1}$ ). Residues of cis-chlordane were positively

Table 1 -continued

\begin{tabular}{|c|c|c|c|c|c|c|c|c|c|}
\hline \multirow[b]{2}{*}{$\begin{array}{l}\mathrm{S} \\
\mathrm{C}\end{array}$} & \multicolumn{9}{|c|}{ ppm fresh weight in blubber } \\
\hline & Dieldrin & opDDT & TDE & DDE & ppDDT & DDTs & PCBs & $\begin{array}{c}\% \text { DDE } / \\
\text { tDDT }\end{array}$ & $\begin{array}{c}\% \text { DDT } / \\
\text { PCB }\end{array}$ \\
\hline
\end{tabular}

\begin{tabular}{|c|c|c|c|c|c|c|c|c|c|}
\hline 1 & $0.05 \pm 0.05$ & - & $0.2 \pm 0.1$ & $0.95 \pm 0.05$ & $0.60 \pm 0.30$ & $1.75 \pm 0.35$ & $1.40 \pm 0.10$ & $57.1 \pm 14.0$ & $124 \pm 16$ \\
\hline \multirow[t]{2}{*}{2} & 0 & - & 0.1 & 0.8 & 0.20 & 1.10 & 0.7 & 72.7 & 157 \\
\hline & 0 & - & 1.6 & 9.9 & 4.0 & 15.5 & 4.00 & 63.9 & 387 \\
\hline \multirow[t]{2}{*}{3} & $0.05 \pm 0.007$ & - & $0.18 \pm 0.02$ & $0.96 \pm 0.22$ & $0.56 \pm 0.14$ & $1.69 \pm 0.38$ & $1.24 \pm 0.32$ & $56.3 \pm 0.7$ & $146 \pm 45.4$ \\
\hline & 0.01 & - & 0.12 & 0.83 & 0.35 & 1.30 & 0.69 & 63.8 & 188 \\
\hline \multirow[t]{2}{*}{4} & 0.007 & - & 0.58 & 6.67 & 0.13 & 7.38 & 5.00 & 90.4 & 148 \\
\hline & 0.05 & - & 0.08 & 1.19 & 0.17 & 1.44 & 2.00 & 82.6 & 72 \\
\hline \multirow[t]{2}{*}{5} & $0.26 \pm 0.34$ & $6.49 \pm 6.02$ & $3.37 \pm 2.83$ & $63.7 \pm 51.9$ & $20.7 \pm 19.3$ & $102.1 \pm 83.2$ & $5.50 \pm 1.92$ & $57.5 \pm 19.3$ & $1610 \pm 1026$ \\
\hline & $0.17 \pm 0.16$ & $0.77 \pm 0.93$ & $1.26 \pm 1.15$ & $16.7 \pm 21.3$ & $5.77 \pm 9.64$ & $28.4 \pm 36.2$ & $3.35 \pm 4.26$ & $60.2 \pm 11.1$ & $754 \pm 328$ \\
\hline 6 & 0 & 0 & 0.72 & 7.2 & 1.80 & 11.02 & 5.20 & 65.3 & 212 \\
\hline \multirow[t]{2}{*}{7} & 0.17 & - & 2.90 & 41.84 & 6.43 & 51.18 & 7.26 & 81.76 & 704.55 \\
\hline & 0.38 & - & 8.00 & 41.17 & 14.17 & 63.33 & 9.14 & 65.00 & 692.62 \\
\hline
\end{tabular}

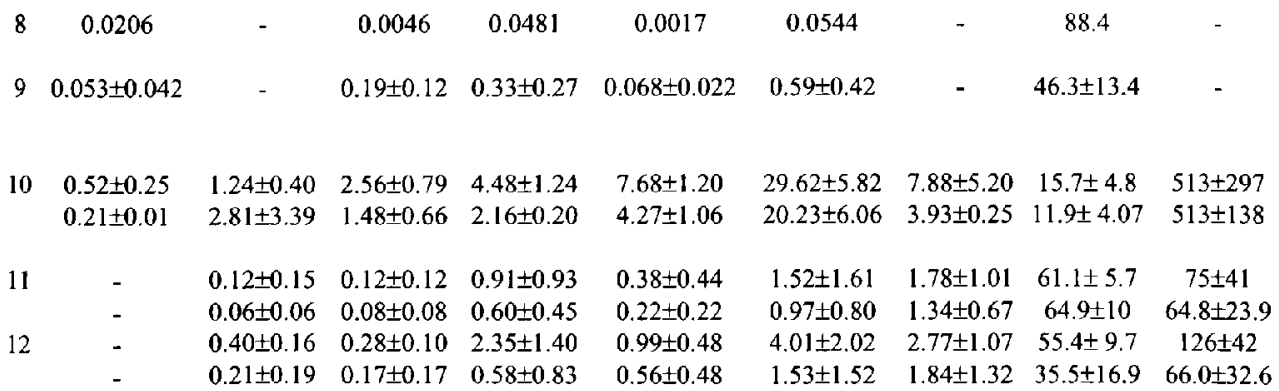

$13 \quad 0.19$

0.35

2.1

0.32

2.77

$<0.4 \quad 75.8$

693 
identified in two male franciscanas $\left(0.53 \pm 0.41 \mu \mathrm{g} \cdot \mathrm{g}^{-1}\right)$ and in one striped dolphin female $\left(0.18 \mu \mathrm{g} . \mathrm{g}^{-1}\right)$. Oxychlordane, mirex and cis-nonachlor were not found in any of the individuals studied by O'Shea et al. (1980). Tanabe et al. (1996) found extremely low levels of $\alpha-, \beta$ - and $\tau$ - (lindane) HCH in two spinner dolphins from the eastern tropical Pacific.

Lindane and aldrin have also been reported from Bryde's and fin whales caught off Chile, where the mean levels were always below $0.07 \mu \mathrm{g} \cdot \mathrm{g}^{-1}$ (Pantoja et al., 1985). Taruski et al. (1975) found a concentration of $0.1 \mu \mathrm{g} . \mathrm{g}^{1}$ of $\alpha$-chlordane in one of the two humpback whales studied in the Antilles, but in none of the sperm whales from the same region. Dieldrin, the most widespread organochlorine pollutant after DDT and PCBs, was detected in several species and regions although levels were always low, below $0.5 \mu \mathrm{g} . \mathrm{g}^{-1}$.

The tDDT/PCB ratio commonly observed in the surveys was very high (432 \pm 428 in Central America and $293 \pm 249$ in South America) in comparison to that usually found in marine mammals from other geographical locations (Aguilar et al., 1999). This indicates a greater contribution to the organochlorine pollution in this area by agriculture than industry.

By comparison, the DDE/tDDT ratio was about mid-range in Central America $(68 \pm 11)$, and somewhat lower in South America (61 \pm 17$)$, with the exception of the franciscana from Uruguay, from which extremely low values $(14 \pm 4)$ were found. DDE is the main product of the metabolisation of commercial DDT and, in areas where the use of this pesticide has been abandoned, its relative abundance in the tissues of top predator marine mammals usually ranges from 55-70\% (Addison et al., 1984; Aguilar, 1984). Therefore, these comparatively low ratios suggest a recent usage of the pesticide in the region, particularly in the southern part of the continent. As mentioned above, the case of the franciscana from Uruguay was exceptional, with a mean percentage quite close to that of typical commercial formulations, clearly indicating that an input of DDT into the ecosystem had occurred just before the samples were collected (O'Shea et al., 1980).

\section{Heavy metals}

Although heavy metals are naturally present in the environment in some areas, human activity has substantially increased their abundance, particularly in the last century. Some, but not all, heavy metals bioaccumulate and biomagnify through food webs, and their tissue concentrations increase progressively with age (Aguilar et al., 1999). In contrast to the organochlorine pollutants, heavy metals are non-lipophilic and their distribution in tissues basically follows their chemical affinities. Mercury, copper, zinc and other heavy metals accumulate mainly in the liver, but cadmium accumulates in the kidney and lead in bone (Honda et al., 1982; André et al., 1990a; b).

Table 2 details published results on heavy metal concentrations in marine mammals from Central and South America. Concentrations of metals are expressed as $\mu \mathrm{g} \cdot \mathrm{g}^{-1}$ wet weight. Although information is available on a wide variety of tissues, the present review collates data only on liver, muscle and kidney, the tissues considered to be most representative of metal load in mammals.

\section{Coverage of studies}

As was the case for organochlorines, few marine mammal species have been analysed for heavy metals in Central or South America (Fig. 1). In general, sample sizes have been small and, excluding the studies on spotted dolphins from the eastern tropical Pacific which were carried out on a large sample (André et al., 1990a; b), the total number of animals investigated so far in this regard only comprises 36 individuals from nine species over an 18-year period. 
In Central America, only three species (all odontocetes from the Caribbean region) have been studied: short-finned pilot whales and spinner dolphins from the Lesser Antilles in 1972 (Gaskin et al., 1974) and spotted dolphins from the tropical Pacific waters during 1977-83 (André et al., 1990a; b).

In South America, almost all surveys thus far have been carried out in Argentinean waters (Moreno et al., 1984; Marcovecchio et al., 1990; 1994). Four odontocete species have been examined (pygmy sperm whale, Cuvier's beaked whale, bottlenose dolphin and franciscana), all before 1990 , although the specific dates of sample collection are not specified except for one bottlenose dolphin that was caught in 1982. There is also isolated information from two tucuxi dolphins collected in Surinam in 1971 (Koeman et al., 1972).

In addition to cetaceans, two species of pinnipeds, fur seals from Uruguay and sea lions from Argentina, were also analysed for heavy metals in 1990 and 1983-1985, respectively (Peña et al.. 1988; Gerpe et al., 1990).

\section{Levels}

\section{MERCURY}

The effects of mercury on man and wildlife have long been recognised and mercury has received considerable attention since the first ecotoxicological surveys. Although mercury is mostly released in its inorganic form, where it has limited toxicity, once incorporated into the biota it is transformed into organic derivatives, mainly methyl-mercury, which are readily transferred through the food web and have a much higher potential for toxicity. Mercury has been responsible for several large-scale mortalities or serious impacts both in human and

Table 2a

Heavy metal concentrations (mean $\pm \mathrm{SD}$ ) in different tissues of marine mammals from Central America. Provenance of researchers: 'Canada ${ }^{2}$ France.

\begin{tabular}{|c|c|c|c|c|c|c|c|c|}
\hline \multirow[b]{2}{*}{ Area/Species } & \multirow[b]{2}{*}{ sex } & \multirow[b]{2}{*}{$\mathrm{n}$} & \multirow[b]{2}{*}{ Date } & \multirow[b]{2}{*}{ Tissue } & \multicolumn{3}{|c|}{ Units: ppm wet weight } & \multirow[b]{2}{*}{ Reference } \\
\hline & & & & & tHG & $\mathrm{CH} 3-\mathrm{Hg}$ & $\mathrm{Cd}$ & \\
\hline \multicolumn{9}{|c|}{ STA. LUCIA (LESSER ANTILLES) ${ }^{1}$} \\
\hline \multirow{6}{*}{$\begin{array}{l}\text { Short-finned pilot } \\
\text { whale, } \\
\text { Globicephala } \\
\text { macrorhynchus }\end{array}$} & $\mathrm{m}$ & 4 & 1972 & liver & $105.6 \pm 56.5$ & $3.46 \pm 0.14$ & & Gaskin et al. 1974 \\
\hline & & & & muscle & $3.98 \pm 0.92$ & $2.32 \pm 0.66$ & & \\
\hline & & & & kidney & $8.65 \pm 2.04$ & 1.6 & & \\
\hline & $\mathrm{f}$ & 1 & 1972 & liver & 21.4 & & & \\
\hline & & & & muscle & 4 & 2.4 & & \\
\hline & & & & kidney & 14 & & & \\
\hline \multirow{6}{*}{$\begin{array}{l}\text { Spinner dolphin, } \\
\text { Stenella } \\
\text { longirostris }\end{array}$} & $\mathrm{m}$ & 1 & 1972 & liver & 13 & 1.33 & & Gaskin et al. 1974 \\
\hline & & & & muscle & 0.87 & & & \\
\hline & & & & kidney & 2.68 & & & \\
\hline & $f$ & 1 & 1972 & liver & 6 & 1.88 & & \\
\hline & & & & muscle & 1.33 & 1.33 & & \\
\hline & & & & kidney & 2.28 & & & \\
\hline \multicolumn{9}{|c|}{ EASTERN TROPICAL PACIFIC ${ }^{2}$} \\
\hline \multirow{6}{*}{$\begin{array}{l}\text { Spotted dolphin, } \\
\text { Stenella attenuata }\end{array}$} & $\mathrm{m}$ & 16 & $1977-83$ & liver & $59.99 \pm 53.2$ & & & André et al. $1990 \mathrm{~b}$ \\
\hline & & & & muscle & $2.11+2.00$ & & & \\
\hline & & & & kidney & $4.71 \pm 3.33$ & & & \\
\hline & $\mathrm{f}$ & 28 & $1977-83$ & liver & $64.86 \pm 52.90$ & & & \\
\hline & & & & muscle & $2.31+2.08$ & & & \\
\hline & & & & kidney & $5.50 \pm 3.05$ & & & \\
\hline \multirow{3}{*}{$\begin{array}{l}\text { Spotted dolphin, } \\
\text { Stenella attenuala }\end{array}$} & $\mathrm{m} / \mathrm{f}$ & 27 & $1977-83$ & liver & & & $8.72 \pm 8.79$ & André et al. $1990 \mathrm{a}$ \\
\hline & & & & muscle & & & $0.29 \pm 0.17$ & \\
\hline & & & & kidney & & & $48.69 \pm 26.36$ & \\
\hline
\end{tabular}




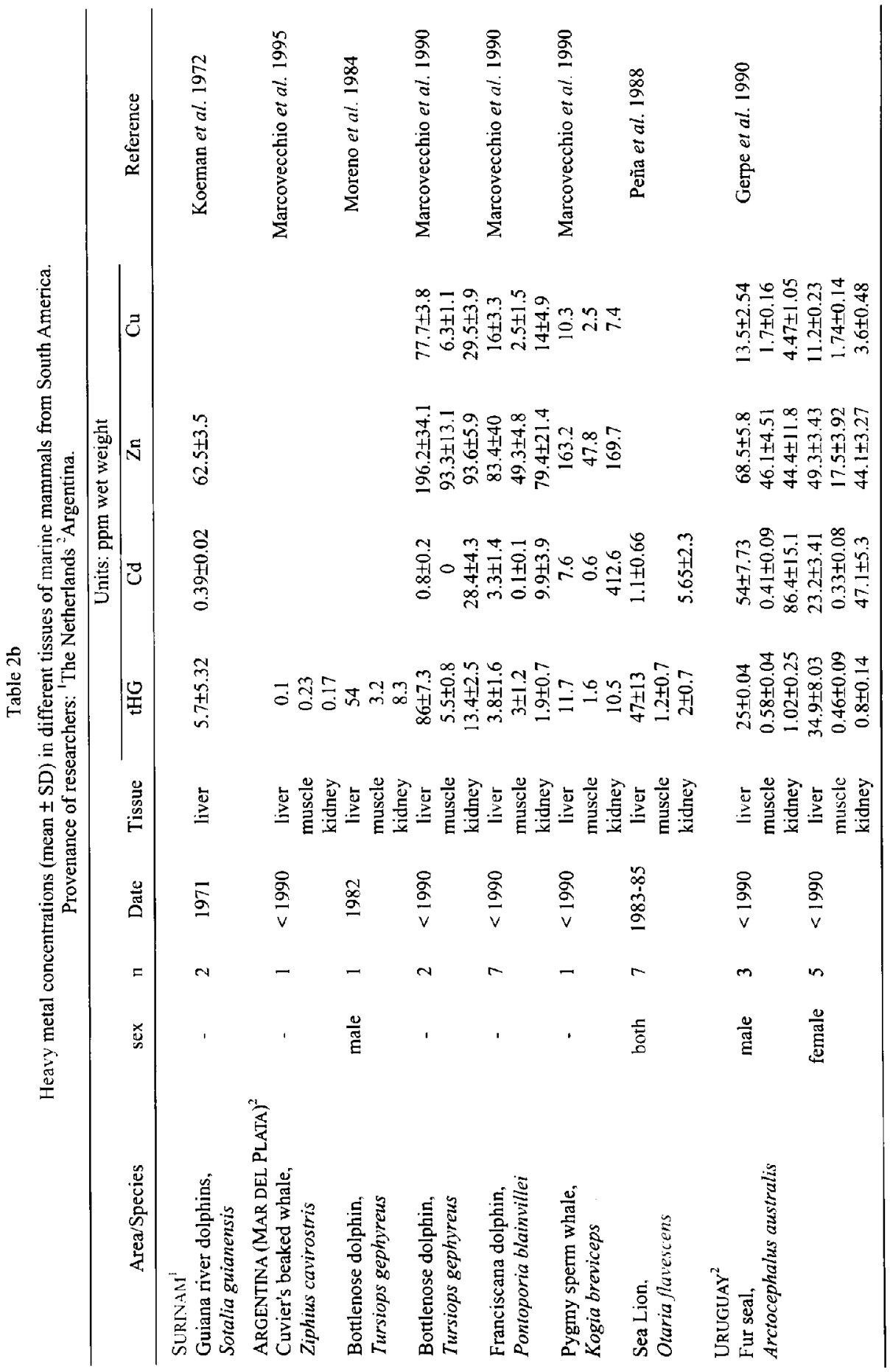


wildlife populations. In mammals, mercury accumulates with age and, in females, it crosses the placental membranes and passes to the milk (Aguilar et al., 1999).

Levels of total mercury (irrespective of whether in its organic or inorganic form) have been determined in all the species studied (Table 2). As expected, mean concentrations in liver were consistently higher than those in muscle or kidney. Levels were extremely variable, ranging from $0.1-106 \mu \mathrm{g} . \mathrm{g}^{-1}$. Liver concentrations reported in marine mammals

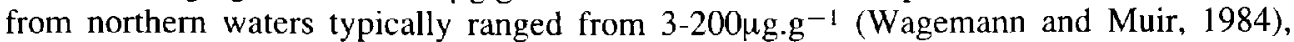
indicating that concentrations of this element in Central and South American cetaceans and pinnipeds are moderate overall. However, marine mammals from the regions where contamination by this metal is likely to be higher, such as the Amazon river, have not been studied in this regard.

Methyl-mercury has only been analysed in five short-finned pilot whales from the Caribbean (Gaskin et al., 1974). The proportion of methyl-mercury in relation to that of total mercury in the liver was very low $(3 \%)$, in contrast to the situation observed in the muscle $(60 \%)$ and kidney $(18 \%)$ of the same individuals. This is a common finding in marine mammals. In most vertebrates, methyl-mercury is the most abundant derivative of all the forms of mercury present in tissues. However, the fraction of organic mercury in the liver of marine mammals heavily contaminated by this element is much lower than in the rest of the body, an anomaly explained by the apparently unique ability of marine mammals to demethylate organic mercury to transform it into its inorganic form and, in this way, reduce its toxic impact (Koeman et al., 1975). The mean levels of total-mercury (tHg) found in the liver of short-finned pilot whales, particularly in males, were high $\left(106 \mu \mathrm{g} \cdot \mathrm{g}^{-1}\right)$. The authors of the paper explained these high levels by the fact that the Caribbean is a tectonically active region with a higher than average environmental level of mercury. However, spinner dolphins from the same region presented much lower levels $\left(6-13 \mu \mathrm{g} . \mathrm{g}^{-1}\right)$ of $\mathrm{tHg}$ (Gaskin et al., 1974).

The spotted dolphin from the tropical waters of the Pacific is the only species from which sufficient numbers of individuals have been studied to identify variations of mercury levels with age, body weight, sex, geographical origin or date of sampling (André et al., 1990b). Results indicated that the concentration of mercury increases in all organs throughout the dolphin's life, confirming previous observations in other marine mammal species (Aguilar et al., 1999). It was also found that concentrations increased when the capture site was close to the Equator.

The highest mercury concentrations in tissues from marine mammals from South America $\left(86 \pm 7.3 \mu \mathrm{g} \cdot \mathrm{g}^{-1}\right)$ were found in two bottlenose dolphins from Argentina (Marcovecchio et al., 1990). The reasons for this were not evident, although the authors of the study attributed the high levels observed to the fish-eating habits of the species.

\section{CADMIUM}

The cadmium industry has increased considerably since the first World War and in particular during the last 25 years (Wagemann et al., 1990). However, it is difficult to determine whether anthropological activity has had a major impact on the natural levels of this element in the biosphere (André et al., 1990a). Cadmium accumulates in the kidney and, in long-lived mammals, its levels usually increase with age; tissue concentrations are generally higher in females than in males (Aguilar et al., 1999). In 27 spotted dolphins from the eastern tropical Pacific, André et al. (1990a) reported positive relationships of cadmium renal concentrations with both age and body weight. Peculiar to cadmium is a large individual variation in levels (Wagemann and Muir, 1984).

Mean cadmium concentrations in marine mammals from Central and South America were high overall (5.65-402 $\mu \mathrm{g} . \mathrm{g}^{-1}$ in kidney). Of the seven species examined, two had higher 
mean levels than those in the range typical for northern marine mammals (Wagemann and Muir, 1984). The lowest renal mean concentration observed was $5.65 \mu \mathrm{g} \cdot \mathrm{g}^{-1}$, detected in sea lions from Argentina, a level that is still considered to be high. In addition, exceedingly high cadmium concentrations $\left(402 \mu \mathrm{g} . \mathrm{g}^{-1}\right)$ were detected in the kidneys of the oceanic pygmy sperm whale (Marcovecchio et al., 1990), a finding that was attributed to its squid-based diet; squid are known to be large accumulators of cadmium (Martin and Flegal, 1975; Hamanaka and Mishima, 1981).

\section{ZINC AND COPPER}

Zinc and copper are well known pollutants that originate from a wide range of mining and industrial activities. While copper levels usually increase with age, zinc tissue concentrations seldom show any age-related trend (Aguilar et al., 1999). For both metals, the main body site for accumulation appears to be the liver. No data on concentrations of zinc or copper are available from marine mammals from Central America. From South America, only five species appear to have been analysed for these metals (Table 2).

Table 2 shows that mean zinc concentrations in fur seals from Uruguay $\left(49 \mu \mathrm{g}^{-g^{-1}}\right.$ in females and $68 \mu \mathrm{g} \cdot \mathrm{g}^{-1}$ in males) appear to fall towards the upper bound of means

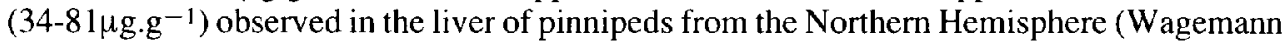
and Muir, 1984). Levels detected in bottlenose dolphins $\left(196 \mu \mathrm{g}^{-1}{ }^{-1}\right)$, franciscanas $\left(83 \mu \mathrm{g} \cdot \mathrm{g}^{-1}\right)$, pygmy sperm whales $\left(163 \mu \mathrm{g} \cdot \mathrm{g}^{-1}\right)$ from Argentina and tucuxis $\left(62 \mu \mathrm{g} \cdot \mathrm{g}^{-1}\right)$ from Surinam are more than double those commonly found in cetaceans $\left(26-59 \mu \mathrm{g} . \mathrm{g}^{-1}\right)$ from the Northern Hemisphere.

In contrast, copper levels from most individuals and species analysed appear to be in the usual range of northern marine mammals, with the exception of two bottlenose dolphins from Argentina, which showed very high concentrations $\left(78 \mu \mathrm{g} . \mathrm{g}^{-1}\right.$ ) of this metal (Marcovecchio et al., 1990).

\section{OTHER METALS}

Apart from the low levels of arsenic $\left(0.17 \mu \mathrm{g} . \mathrm{g}^{-1}\right)$ detected in tucuxis by Koeman et al. (1972), data for other metals are limited to a survey on concentrations of lead in sea lions from Argentina (Peña et al., 1988). In this survey, several tissues from seven individuals were analysed but only the bone from three of them presented detectable levels ( $1.6 \pm$ $\left.0.2 \mu \mathrm{g} \cdot \mathrm{g}^{-1}\right)$.

\section{DISCUSSION}

The central and southern regions of the American continent support a rich and diverse marine mammal fauna. However, despite the occurrence of extensive agricultural, mining and industrial activities that can be expected to have released vast amounts of pollutants into the marine environment, little attention has been paid to the potential impact of such pollutants on local marine mammal populations. This is reflected in the small number of papers published in the scientific literature on this specific subject, and in the limited scope and heterogeneous sample composition of most of them, as compared to those available from other similarly developed regions of the world.

Only two groups of local researchers. One from Argentina and the other from Chile, have to date published results on the subject. The group from Chile focused its studies on organochlorines in large whales from the Southern Pacific (Pantoja ' 1 al., 1984; 1985), while the group from Argentina investigated the incidence of heavy metals in a variety of odontocete and pinniped species (Peña et al., 1988; Gerpe et al., 1990; Marcovecchio et al., 
1990; 1994). Although other local groups, mostly from Mexico and Brazil, have also carried out research on the effects of pollutants on marine mammals, their results have not yet been published in the refereed scientific literature.

In addition, a number of researchers from North America and Europe, sometimes in collaboration with local researchers, have undertaken investigations on the effects of pollutants on marine mammals from the region. Although these studies have usually focussed on the northern fringe of the South American continent or the Caribbean region, some have been undertaken along the coasts of Argentina and Uruguay (Koeman et al., 1972; Gaskin et al., 1974; Taruski et al., 1975; O’Shea et al., 1980; André et al., 1990a; b; Borrell et al., 1996).

Most studies were carried out on specimens obtained opportunistically from strandings or fishing interactions and are therefore limited in their sample size and, by extension, in their representativeness of the actual toxicological situation of the populations subject to study. Indeed, only three of them are extensive in terms of sample size, but each deals with only a single species (André et al., 1990a; b; Borrell et al., 1996).

The available data suggest that, overall, organochlorine pollutants, although ubiquitous in the region, do not reach the levels attained in the highly industrialised latitudes of the Northem Hemisphere. In the marine mammals studied, there is a clear predominance of organochlorine compounds of agricultural rather than industrial origin. In some cases (e.g. the DDTs), the pollutant profile found differed little from the original commercial formulations. This indicates that their use was relatively recent, and in some cases virtually contemporary with the time of study.

Information on heavy metals reveals an irregular picture. Although mercury levels were moderate overall, no information was available on concentrations in the tissues of marine mammals found in areas with higher potential risk of pollution, such as the tributaries of the Amazon River affected by mining, or the mouth and adjacent waters of this river. In contrast, cadmium and zinc concentrations were higher overall than those in the range typical for northern marine mammals, while copper and lead levels were comparatively low. However, information on these latter metals was extremely limited.

The lack of comprehensive, long-term studies, renders it impossible to present a reliable evaluation of the impact of pollutants on the marine mammals from the region. This is unfortunate considering that Central and South America harbour a number of endemic cetacean species (e.g. tucuxi, Sotalia fluviatilis, black dolphin, Cephalorhynchus eutropia, Peale's dolphin, Lagenorhynchus australis, boto, Inia geoffrensis, franciscana, Pontoporia blainvillei, Burmeister's porpoise, Phocoena spinipinnis), which are often riverine or coastal, and thus likely to be highly susceptible to the effects of these pollutants. Information on pollutant levels in pinnipeds is equally fragmentary, whilst that on Amazonian manatees or the Central American populations of the West Indian manatee is totally lacking despite their critical conservation status and the comparatively abundant data available from the Florida manatee (O'Shea et al., 1984; Ames and van Vleet, 1996). The impact of pollutants has been identified as a potentially major factor in the conservation of marine mammals (IWC, 1994; Reijnders, 1996) and, given the paucity of data on this subject from central and southern America, further studies are urgently needed to ensure proper management of the local populations and species.

\section{ACKNOWLEDGEMENT}

This research was funded by the Comisión Interministerial de Ciencia y Tecnología (CCYT) Project AMB 399/94. 


\section{REFERENCES}

Addison, R.F., Brodie, P.F. and Zinck, M.E. 1984. DDT has declined more than PCBs in eastern Canadian seals during the 1970s. Environ. Sci. Technol. 18:935-7.

Aguilar, A. 1984. Relationship of DDE/tDDT in marine mammals to the chronology of DDT input into the ecosystem. Can. J. Fish. Aquat. Sci. 41:840-4.

Aguilar, A. 1987. Using organochlorine pollutants to discriminate marine mammal populations: a review and critique of the methods. Mar. Mammal Sci. 3(3):242-62.

Aguilar, A., Borrell, A. and Pastor, T. 1999. Biological factors affecting variability of persistent pollutant levels in cetaceans. J. Cetacean Res. Manage. (special issue 1):83-116.

Ames, A.L. and van Vleet, E.S. 1996. Organochlorine residues in the Florida manatee, Trichechus manatus latirostris. Mar. Poll. Bull. 32(4):374-7.

André, J.M., Amiard, J.C., Amiard-Triquet, C., Boudou, A. and Ribeyre, F. 1990a. Cadmium contamination of tissues and organs of delphinid species (Stenella attenuata) - influence of biological and ecological factors. Ecotoxicol. Environ. Saf. 20:290-306.

André, J.M., Ribeyre, F. and Boudou, A. 1990b. Mercury contamination levels and distribution in tissues and organs of Delphinids (Stenella attenuata) from the Eastern Tropical Pacific, in relation to biological and ecological factors. Mar. Environ. Res. 30:43-72.

Borrell, A. and Reijnders, P.J.H. 1999. Summary of temporal trends in pollutant levels observed in marine mammals. J. Cetacean Res. Manage. (special issue 1):149-55.

Borrell, A., Pastor, T., Aguilar, A., Corcuera, J. and Monzón, F. 1996. DDT and PCBs in Pontoporia blainvillei from Argentina. Age and sex trends. Eur. Res. Cetaceans [Abstracts] 9:273-6.

Corcuera, J., Monzón, F., Aguilar, A., Borrell, A. and Raga, J.A. 1995. Life history data, organochlorine pollutants and parasites from eight Burmeister's porpoises, Phocoena spinipinnis, caught in northern Argentine waters. Rep. int. Whal. Commn (special issue) 16:365-72.

De Swart, R.I.. Ross, P.S., Vedder, L.J., Timmerman, H.H., Heisterkamp, S.H., Van Loveren, H., Vos, J.G., Reijnders, P.J.H. and Osterhaus, A.D.M.E. 1994. Impairment of immune function in harbour seals (Phoca vitulina) feeding on fish from polluted waters. Ambio 23:155-9.

Duinker, J.C., Zeinstra, T., Hillebrand, M.T.J. and Boon, J.P. 1989. Individual chlorinated biphenyls and pesticides in tissues of some cetacean species from the North Sea and the Atlantic Ocean: tissue distribution and biotransformation. Aquat. Mamm. 15(3):95-124.

Gaskin, D.E., Smith, G.J.D., Arnold, P.W. and Louisy, M., V. 1974. Mercury, DDT, Dieldrin, and PCB in two lesser species of odontoceti (Cetacea) from St. Lucia, Lesser Antilles. J. Fish. Res. Board Can. 31(7): 1235-9.

Gerpe, M., Moreno, J., Pérez, A., Bastida, R., Rodriguez, D. and Marcovecchio, J. 1990. Trace metals in the southamerican fur seal, Arctocephalus australis (Zimmermann, 1783). Proceedings of the 4th International Conference on Environmental Contamination, Barcelona: 591-593.

Hamanaka, T. and Mishima, S. 1981. Cadmium and zinc concentrations in marine organisms in the northern north Pacific Ocean. Res. Inst. North Pac. Fish. Hokkaido Univ. (special volume): 191-206.

Honda, K., Tatsukawa, R. and Fujiyama, T. 1982. Distribution characteristics of heavy metals in the organs and tissues of striped dolphin, Stenella coeruleoalba. Agric. Biol. Chem. $46(12): 3011-21$.

International Whaling Commission. 1994. Chairman's Report of the Forty-Fifth Annual Meeting. Rep. int. Whal. Commn 44:11-39.

Koeman, J.H., Peeters, W.H.M., Smit, C.J., Tjioe, P.S and de Goey, J.J.M. 1972. Persistant chemicals in marine mammals. TNO-Nieun's 27:570-8.

Koeman, J.H., van de Ven, W.S.M., de Gocij, J.J.M., Tjioe, P.S. and van Haaften, J.L. 1975. Mercury and selenium in marine mammals and birds. Sic. Total Environ. 3:279-87.

Marcovecchio, J.E., Moreno, V.J., Bastida, R.O., Gerpe, M.S. and Rodríguez, D.H. 1990. Tissue distribution of heavy metals in small cetaceans from the southwestern Atlantic Ocean. Mar . Poll. Bull. 21(6):299-304.

Marcovecchio, J.E., Gerpe, M.S., Bastida, R.O., Rodríguez, D.H. and Morón. S.G. 1994. Environmental contamination and matrine mammals in coastal waters from Argentina: an overview. Sci. Total Environ. 154:141-51.

Martin, J.H. and Flegal, A.R. 1975. High copper concentrations in squid liver in association with elevated levels of silver, cadmium and zinc. Mat. Biol, 30:51-5.

Moreno, V.J., Pérez, A., Bastida, R.O., Moreno, J.E.A. and Malaspina, A.M. 1984. Distribución de mercurio total en los tejidos de un delfín de nariz de botella (Tursiops gephyreus Lahille, 1908) de la provincia de Buenos Aires (Argentina). INIDEP 4:93-102.

O'Shea, T.J., Brownell, R.L., Clark, D.R., Walker, W.A., Gay, M.L. and Lamont, T.G. 1980. Organochlorine pollutants in small cetaceans from the Pacific and South Atlantic Oceans, November $1968-$ June 1976. Pestic. Monit. J. 14(2):35-46. 
O'Shea. T.J.. Moore, J.F. and Kochman, H.Y. 1984. Contaminant concentrations in manatees in Florida. J. Wildl. Manage. $48(3): 74 l-8$.

Pantoja, S., Pastene, L.. Becerra, J., Silva, M. and Gallardo, V.A. 1984. DDTs in Balaenopterids (Cetacea) from the Chilean coast. Mar. Poll. Bull. 15(12):451.

Pantoja, S., Pastene, L., Becerra, J., Silva, M. and Gallardo, V.A. 1985, Lindane, aldrin and dieldrin in some Chilean Cetacea. Mar. Poll. Bull. 16(6):255.

Peña. N.I.. Moreno, V.J., Marcovecchio, J.E, and Pérez, A. 1988. Total mercury, cadmium and lead distribution in tissues of the southern sea lion (Otaria flavescens) in the ecosystem of Mar del Plata, Argentina. pp. 14()-6. In: U. Seelinger, L.D. deLacerda and S.R. Patchineelam (eds.) Metals in Coastal Environments of Latin America. Springer Verlag, Berlin.

Reijnders, P.J.H. 1986. Reproductive failure in common seals feeding on fish from polluted coastal waters. Nature, Lond. 324:456-7.

Reijnders. P.J.H. 1996. Organohalogen and heavy metal contamination in cetaceans: observed effects, potential impact and future prospects. pp. 205-17. In: M.P. Simmonds and J.D. Hutchinson (eds.) The Consemation of Whales and Dolphins: Science and Practice. John Wiley and Sons Ltd, Chichester, England. $+76 \mathrm{pp}$.

Reijnders, P.J.H. Donovan, G.P., Aguilar, A. and Bjørge, A. 1999. Report of the Workshop on Chemical Pollution and Cetaceans. J. Cetacen Res. Manage. (special issue 1):1-42.

Tanabe. S., Kumaran, P., Iwata, H., Tatsukawa, R. and Miyazaki, N. 1996. Enantiomeric ratios of a-hexachlorocyclohexane in blubber of small cetaceans. Mar. Poll. Bull. 32(1):27-31.

Taruski. A.G., Olney, C.E. and Winn, H.F. 1975. Chlorinated hydrocarbons in cetaceans. J. Fish. Res. Board Can. 32(11):2205-9.

Wagemann. R. and Muir, D.G.C. 1984. Concentrations of heavy metals and organochlorines in marine mammals of northern waters: overview and evaluation. Can. Tech. Rep. Fish. Aquat. Sci. 1279:1-97.

Wagemann, R.. Stewart, R.E.A., Beland, P. and Desjardins, C. 1990. Heavy metals and selenium in tissues of beluga whales, Delphinapterus leucas, from the Canadian Arctic and the St Lawrence Estuary. pp. 191-206. In: T.G. Smith, D.J. St Aubin and J.R. Geraci (eds.) Advances in Research on the Beluga Whale, Delphinapterus leucas. Can. Bull. Fish. Aqua. Sci. 224. 206pp. 